\title{
KODE ETIK GURU DALAM MENINGKATKAN PROFESIONALISME PENDIDIK; REAKTUALISASI DAN PENGEMBANGAN KODE ETIK GURU DI MADRASAH ALIYAH DARUL AMIN PAMEKASAN
}

\author{
Akhmad Zacky AR \\ (STIKA An Nuqayah Guluk-Guluk Sumenep)
}

\begin{abstract}
Abstrak:
Dalam profesi keguruan terdapat kode etik untuk menjunjung tinggi martabat profesi, untuk menjaga dan memelihara kesejahteraan anggotanya, untuk meningkatkan pengabdian para anggota profesi, untuk meningkatkan mutu profesi dan untuk meningkatkan mutu organisasi profesi. Dengan kode etik, guru diharapkan mampu berfungsi secara optimal dan profesional, terutama dalam mengembangkan karakter dan budi pekerti anak didik dan menjunjung wibawa lembaga serta profesi pendidik. Penelitian ini bertujuan untuk mendekripsikan penerapan kode etik sekolah di MA Darul Amin Pamekasan dan bagaimana kode etik sekolah bisa meningkatkan profesionalitas dalam pembelajaran. Dalam penelitian ini, penulis menggunakan pendekatan dan jenis penelitian deskriptif kualitatif, dengan sumber data dari kepala sekolah MA Darul Amin pamekasan, guru dan sumber sekunder yang relevan. Hasil dari penelitian ini adalah bahwa kode etik sekolah di MA Darul Amin Pamekasan merupakan cara dalam peningkatan profesionalitas guru agar taat kepada peraturan-peraturan yang telah ditetapkan dan disepakati oleh pihak pengelola MA Darul Amin Pamekasan. Kode etik guru yang dikembangkan menjadi kode etik sekolah diangggap metode yang efektif dalam proses peningkatan profesionalitas guru di sekolah ini.
\end{abstract}

Kata Kunci: Kode Etik Guru, Profesionalisme, Pendidik, Reaktualisasi. 


\begin{abstract}
:
There is a set of ethical codes in the teaching profession in purpose of upholding professional values, maintaining the prosperity for the members, increasing service quality as well as professional and organizational quality. With the ethics, this is a big hope that teachers can work optimally and professionally in developing students' character as well as institutional legitimation and teaching profession. This research is aimed to describe the implementation of ethical codes in Islamic High School Darul Amin Pamekasan and how the ethics improves professionalism in learning process. In this descriptive-qualitative research, the primary information comes from the school principal, teachers, and other relevan resources. The finding shows that the ethical code is a way of monitoring and controlling teacher to improve their professionalism based upon agreement in the school. The teacher ethical code is then translated and developed as the school ethical code which is effectively improve the teacher professionalism.
\end{abstract}

\title{
Keywords: Teacher Ethical Code, Professionalism, Educator, Reactualization.
}

\section{A. Pendahuluan}

Sebagai makhluk yang bermasyarakat (zoon politicon) ${ }^{1}$ manusia tidak bisa lepas dari berhubungan dengan kondisi lingkungan di sekitarnya di mana ia tinggal dan hidup. Manusia dalam melakukan aktivitasnya sehari-hari selalu disertai dengan norma atau aturan yang mengikat, baik aktivitas manusia tersebut yang berhubungan dengan Tuhan, sesama manusia, lingkungan maupun diri sendiri. Inilah yang kemudian disebut "etik". ${ }^{2}$

Etik dalam konteks ini mengindikasikan adanya ilmu adab, yaitu ilmu yang mempelajari segala kebaikan dan keburukan di dalam hidup manusia semuanya, teristimewa yang mengenai gerak-gerik pikiran dan rasa yang dapat merupakan pertimbangan dan perasaan, sampai mengenai tujuannya yang dapat merupakan perbuatan. $^{3}$

Menurut pendapat William Lillie, bahwa: "Ethics as the normative science of conduct of human being living in societies - a science which judges this conduct to be right or wrong, to be good or bad, or in some similar way". ${ }^{4}$ Etik adalah ilmu pengetahuan tentang norma/aturan ilmu pengetahuan tentang tingkah laku kehidupan manusia dalam masyarakat, yang mana ilmu pengetahuan tersebut

1 Lihat pernyataan Aristoteles yang dikutip oleh Ansory al Mansor dalam buku Jalan Kebahagiaan yang Diridhai (Jakarta : Raja Grafindo Persada, 1997), Cet. 1, 43.

2 Syaiful Bahri Djamarah, Guru dan Anak Didik Dalam Interaksi Edukatif" (Jakarta : Rineka Cipta, 2000), 49.

3 Team Pembina Mata Kuliah Didaktik Metodik / Kurikulum IKIP Surabaya, Pengantar Didaktik Metodik Kurikulum PBM, Edisi I (Jakarta: Rajawali, 1989), Cet 4,16.

${ }^{4}$ William Lillie, An Introduction to Ethics (New York : Barnes and Noble, 1996), 1-2.

Jurnal Pendidikan Agama Islam

Volume 4 Nomor 2 Nopember 2016

ISSN(p) 2089-1946\& ISSN(e) 2527-4511

Hal. 272 - 292 
menentukan tingkah laku itu benar atau salah, baik atau buruk atau sesuatu yang semacamnya.

Dalam suatu jabatan atau profesi sering kita temukan istilah kode etik. Di mana kode etik tersebut adalah sebagai kontrol dari semua aktivitas profesi yang berhubungan dengan profesinya. Dalam buku Profesi Keguruan, kode etik pada suatu profesi adalah untuk menjunjung tinggi martabat profesi, untuk menjaga dan memelihara kesejahteraan anggotanya, untuk meningkatkan pengabdian para anggota profesi, untuk meningkatkan mutu profesi dan untuk meningkatkan mutu organisasi profesi. ${ }^{5}$ Guru diharapkan mampu berfungsi secara optimal terutama dalam meningkatkan pendidikan watak dan budi pekerti agar dapat mengembalikan wibawa lembaga dan tenaga kependidikan. ${ }^{6}$

Maka, guru sebagai tenaga professional dalam hal ini memerlukan pedoman atau kode etik guru agar terhindar dari segala bentuk penyimpangan. Kode etik menjadi pedoman baginya untuk tetap profesional (sesuai dengan tuntutan dan persyaratan profesi). Setiap guru yang memegang keprofesionalnya sebagai pendidik akan selalu berpegang pada kode etik guru. Sebab kode etik guru ini sebagai salah satu ciri yang ada pada profesi itu sendiri. ${ }^{7}$ Sebagaimana petugas profesional lainnya, seperti dokter, hakim, peneliti, yang tugasnya dituntut mematuhi dan terikat oleh kode etik jabatan, maka seorang guru sebagai petugas profesional juga diwajibkan mematuhi dan terikat oleh suatu kode etik dalam menjalankan tugasnya membimbing dan mendidik anak. ${ }^{8}$

Kode etik jabatan khususnya tentang Kode Etik Profesi Tenaga Kependidikan (sementara ini tenaga kependidikan umumnya masih bermakna "guru") yang berlaku di Indonesia adalah sebagaimana yang di keluarkan oleh Persatuan Guru Republik Indonesia (PGRI). ${ }^{9}$ Maka dari itu di MA Darul Amin Pamekasan mengembangkan kode etik guru Indonesia ke kode etik sekolah demi menciptakan profesionalitas guru dalam pembelajaran. Hal ini di sebabkan karena ada salah satu guru yang mengajar di sekolah lain selain di MA Darul Amin Pamekasan sehingga ada jam pelajarannya yang bentrok, yang menyebkan proses belajar mengajar tergaggu. Maka dari itu pihak sekolah menegur guru tersebut dan memberikan peringatan secara tegas. Supaya tidak terulang lagi masalah tersebut. MA Darul Amin Pamekasan menerapkan kode etik dalam mengembangkan dan memajukan sekolah menghadapi tantangan atau hambatan

${ }^{5}$ Soetjipto dan Raflis Kosasi. Profesi Keguruan (Jakarta: Rineka Cipta, 1999), 32.

${ }^{6}$ Subagyo., dkk., Pendidikan Kewarganegaraan (Semarang : IKIP Semarang Press, 2002), Cet. III, 147.

7 Sardiman, Interaksi dan Motivasi Belajar Mengajar Pedoman Bagi Guru dan CalonGuru, Edisi I (Jakarta : Rajawali, 1992), Cet. 4, 148.

8 Soetomo, Dasar-dasar Interaksi Belajar Mengajar (Surabaya : Usaha Nasional, 1993), Cet. 1, 264.

${ }^{9}$ Sutomo, dkk., Profesi Kependidikan (Semarang : IKIP Semarang Press, 1998), Cet. 1, 44-45. 
yang datangnya dari dalam maupun dari luar sekolah yang dapat mengganggu proses belajar mengajar.

Kode etik sekolah tersebut di dalamnya memuat peraturan yang mengatur aktifitas profesional guru di sekolah, sehingga diharapkan guru dalam menjalankan profesinya akan mempunyai arah dan tanggung jawab bukan sekedar mengejar banyaknya SKS yang di tempuh oleh guru. Kode Etik Guru yang di kembangkan oleh MA Darul Amin sangat urgen sekali dalam menciptakan proses pendidikan yang total dan maksimal bagi proses belajar mengajar siswa di MA Darul Amin Pamekasan.

Keberhasilan pendidikan dapat diukur dengan penguasaan siswa terhadap materi yang telah disampaikan oleh guru di dalam kelas. Namun, operasionalnya keberhasilan itu banyak pula ditentukan oleh manajemen pendidikan di samping dipengaruhi oleh beberapa faktor pendidikan yang harus ada dan juga terkait di dalamnya. Faktor tersebut adalah: (1) guru, (2) materi, dan (3) siswa.

Ketiga komponen utama dalam pengajaran tersebut saling berkaitan. Akan tetapi, faktor guru merupakan faktor paling dominan dalam kegiatan belajarmengajar. Guru sebagai perencana sekaligus sebagai pelaksana pembelajaran serta pemberi balikan untuk memotivasi siswa dalam melaksanakan tugas belajar. Hal ini menunjukkan bahwa posisi guru dalam dunia pendidikan sangat penting. Berdasarkan fungsi dan perannya yang sangat besar itu, maka idealnya seorang guru harus memiliki keprofesionalan dalam menjalankan tugasnya.

Guru merupakan profesi, maka untuk menjadi guru harus memiliki sertifikasi dan etika profesi. Program sertifikasi dilakukan untuk meningkatkan keprofesionalan guru seperti yang telah dilakukan oleh Direktorat Pembinaan Perguruan Tinggi Agama Islam mlalui Proyek Peningkatan Mutu Pendidikan Dasar.

Guru mempunyai kewajiban untuk mengawasi dan membantu murid dalam kegiatan belajar mengajar. Sekaligus mereka dituntut agar meningkatkan dirinya menjadi guru yang profesional sehingga guru harus memiliki kompetensi dalan kegiatan belajar mengajar seperti menguasai bahan pelajaran sekolah, menguasai proses belajar mengajar, menguasai penggunaan media dan sumber, dapat mengevaluasi hasil belajar siswa, dapat memotivasi siswa dalam belajar dan lainlain.

Penelitian Suyono tahun 1998 tentang kualitas guru di berbagai jenjang pendidikan menunjukkan bahwa : (1) guru kurang mampu merefleksikan apa yang pernah ada, (2) dalam pelaksanaan tugas, guru pada umumnya terpancing untuk memenuhi target minimal, yaitu agar siswa mampu menjawab tes dengan baik, (3) para guru enggan beralih dari model mengajar yang sudah mereka yakini tepat, (4) guru selalu mengeluh tentang kurang lengkap dan kurang banyaknya buku paket. Mereka khawatir kalau yang diajarkan tidak sesuai dengan soal-soal yang akan muncul dalam UTS, dan UNAS, (5) kecenderungan guru dalam melaksanakan tugas mengajar hanya memindahkan informasi dan ilmu 
pengetahuan saja. Dimensi pengembangan kemampuan berpikir logis, kritis, dan kreatif kurang mendapat perhatian. ${ }^{10}$

Glickman menjelaskan bahwa seorang akan bekerja secara profesional bilamana seseorang tersebut mempunyai: (1) kemampuan (ability), dan (2) motivasi (motivation). Maksudnya adalah seseorang akan bekerja secara profesional apabila ia memiliki kemampuan kerja yang tinggi dan kesungguhan hati untuk mengerjakan dengan sebaik-baiknya. Sebaliknya, seseorang tidak akan bekerja secara profesional bilamana hanya memiliki salah satu diantara dua persyaratan di atas. ${ }^{11}$

Guru dapat dikatakan professional apabila memiliki kemampuan tinggi dan motivasi kerja tinggi. Guru yang memiliki motivasi yang rendah biasanya kurang memberikan perhatian kepada siswa, demikian pula waktu dan tenaga yang dikeluarkan untuk meningkatkan mutu pembelajaran sangat sedikit. Sebaliknya, guru yang memiliki motivasi tinggi biasanya tinggi sekali perhatiannya kepada siswa, demikian pula waktu yang disediakan untuk peningkatan mutu pendidikan sangat banyak.

Guru yang memahami kedudukan dan fungsinya sebagai pendidik yang profesional selalu berkeinginan untuk tumbuh dan berkembang sebagai perwujudan perasaan dan sikap tidak puas terhadap pendidikan yang telah diterimanya dan sebagai pernyataan dan kesadaran terhadap perkembangan dan kemajuan bidang tugasnya yang harus diikuti sejalan dengan kemajuan ilmu pengetahuan dan teknologi, pengalaman profesional yang berharga mungkin diperoleh oleh guru yang berani dan selalu bersedia mewujudkan ide atau gagasan dan mengembangkan proses belajar mengajar di kelas dan di lingkungan sekitar.

\section{B. Kode Etik Guru dalam Konteks Historis}

Dalam pembahasan ini, akan diterangkan secara singkat tentang sejarah lahirnya Kode Etik Guru. Adapun untuk menelusuri sejarahnya terlebih dahulu kita melihat ke belakang istilah adanya kode etik yang digunakan secara formal. Istilah kode etik tenaga kependidikan yang dirumuskan secara tertulis untuk pertama kalinya oleh The National Education Association (NEA) pada tahun 1929, yaitu "A Code Ethics for The Teaching Profession". Kemudian kode etik ini mengalami perbaikan dan revisi pada tahun 1941, 1953 dan terakhir tahun 1963. The National Education Association (NEA) ini merupakan organisasi professional dalam bidang pendidikan di Amerika. ${ }^{12}$

${ }^{10}$ Hadiyanto, Mencari Sosok Desentralisasi Manajemen Pendidikan Indonesia (Jakarta: Rineka Cipta, 2004), 18-19.

11 Ibrahim Bafadal, Peningkatan Profesionalisme Guru Sekolah Dasar (Jakarta: Bumi Aksara, 2004), 5.

12 Bafadal, Peningkatan Profesionalisme Guru Sekolah Dasar, 285. 
Semasa penjajahan Belanda pendidikan di Indonesia diarahkan sesuai dengan kehendak penjajah, sehingga rakyat menjadi bersifat statis, dan para guru yang mengajarpun sangat berpengaruh dalam cara pendidikannya yang bersifat otoriter dan suka menjajah memperlihatkan kekuasaannya, tidak demokratis dan menganaktirikan siswa. Sehingga muncullah tokoh pendidikan yang bernama Ki Hajar Dewantoro, yang pertama kali mendirikan sekolah di Indonesia (Perguruan Taman Siswa). Di mana beliau memberi buah pikiran kepada kita mengenai tata cara akhlak guru. Walaupun istilah kode etik guru tidak dipakai oleh beliau dalam sistem pendidikannya. Namun beliau menggunakan semboyan yang mencakup 4 pengertian, yaitu ing ngarso sung tulodo (memberi contoh dan suri tauladan bila berada di depan), ing madyo mangun karso (ikut aktif dan giat serta menggugah semangat bila berada di tengah), tut wuri handayani (mendorong dan memepengaruhi bila berada di belakangnya), waspodo purbo waseso (harus selalu waspada dan mengawasi serta sanggup melakukan koreksi). Beliau mengharapkan kiranya semboyan ini dapat diresapi dan diwujudkan sebagai pedoman tata cara akhlak bagi tenaga kependidikan dalam melakukan tugasnya dan dalam kehidupan sehari-hari.

Sebagai bagian yang tidak terlepaskan dari sejarah perjuangan bangsa, guru Indonesia yang juga merupakan bagian dari rakyat Indonesia mempunyai peranan sebagai kebanggaan. Guru Indonesia telah memegang peranan penting bersama rakyat dalam perjuangan merebut, mempertahankan dan mengisi kemerdekaan Indonesia. Keadaan yang demikian itu mengandung konsekuensi adanya kewajiban guru Indonesia untuk melaksanakan tugas dan perannya selaku pembimbing, pendidik, pelindung dan pengasuh. Lahirnya guru Indonesia di zaman modern, di mana bangsa ini benar-benar menjadi bangsa yang cerdas dan berakhlak mulia.

Guru harus memiliki jati diri ke - Indonesia - an. Artinya segenap pola pikir, sikap dan tindakannya senantiasa bertumpu pada sendisendi dan realitas kehidupan bangsa. Guru Indonesia senantiasa berpegang teguh pada jati diri, termasuk di dalam menjawab tantangan globalisasi dan laju arus reformasi. Mengingat tugasnya guru Indonesia semakin lama semakin berat dan semakin kompleks, untuk itu guru Indonesia dituntut berpegang teguh pada jati diri yang telah dimilikinya. Jati diri tersebut merupakan kode etik dan sekaligus sebagai pedoman bagi setiap guru Indonesia yang harus dijunjung tinggi dan dilaksanakan dengan baik dalam kegiatan pribadi maupun organisasi. Sehingga pada tahun 1971 FIP-IKIP Malang telah diadakan seminar tentang Etika Jabatan Guru yang diikuti oleh kepala Perwakilan Departemen P \& K Provinsi Jawa Timur. Kepala-kepala Kabin se-Madya dan Kabupaten Malang, bersama-sama Kepala Sekolah, guru-guru se-Kota Madya serta para Dosen FIP-IKIP Malang. ${ }^{13}$

13 Dalam seminar ini menghasilkan rumusan kode etik jabatan guru yang dituangkan dalam buku kecil, yang mudah dibawa ke mana-mana. Harapan Dekan FIP-IKIP Malang kepada kita 
Selanjutnya tentang Kode Etik Guru Indonesia oleh PGRI merupakan pekerjaan berat yang harus dirumuskan, maka pada Kongres PGRI ke XIII tahun 1873 yang diselenggarakan tanggal 21-25 November 1973 di Jakarta telah menetapkan Kode Etik Guru Indonesia. Sekitar Kongres PGRI 1973 sebuah tim telah membahas, menjajaki dan merumuskan melalaui beberapa tahap dalam forum pertemuan para ahli pendidikan. Mereka berorientasi pada semangat jiwa dan nilai-nilai luhur kepribadian dan budaya bangsa yang tumbuh secara embrioal, kemudian diperbandingkan dengan profesi lain. Sebagai contoh kita mengenal Kode Etik Jurnalistik, Kode Etik Kedoketran, Kode Etik Kehormatan Hakim, Kode Etik Pers (Sapta Prasetya), Sapta Marga ABRI, Tri Brata dan Catur Prasetya Polri dan sebagainya.

Kode Etik Guru Indonesia dalam perumusannya/ waktu kelahirannya mengalami 4 (empat) tahap yaitu : (1) Tahap pembahasan/ perumusan (tahun 1971/1973); (2) Tahap pengesahan (kongres XIII, November 1973); (3) Tahap penguraian (kongres XIV, Juni 1979); (4) Tahap penyempurnaan (kongres PGRI XIV, Juli 1989). ${ }^{14}$

Pada tahun 1973 inilah Kode Etik Guru Indonesia dirumuskan oleh PGRI secara yuridis, yang artinya bahwa apabila para guru melakukan pelanggaran atas kode etik maka akan dikenakan sanksi. Sanksi yang akan dijatuhkan tergantung pada berat ringannya pelanggaran tersebut. Tapi yang lebih berat adalah sanksi moral. Sanksi yang akan dikeluarkan itu tentunya tidak salah dijatuhkan secara langsung dijatuhkan, tetapi melalui beberapa tingkatan, yaitu pertama peringatan/teguran, kedua skorsing, dan ketiga tindakan administratif.

Ketaatan guru pada Kode Etik akan mendorong mereka berperilaku sesuai dengan norma-norma yang dibolehkan dan menghindari norma-norma yang dilarang oleh etika profesi yang ditetapkan oleh organisasi atau asosiasi profesinya selama menjalankan tugas-tugas profesional dan kehidupan sebagai warga negara dan anggota masyarakat. Dengan demikian, aktualisasi diri guru dalam melaksanakan proses pendidikan dan pembelajaran secara profesional, bermartabat, dan beretika akan terwujud.

Kode Etik Guru dibuat oleh organisasi atau asosiasi profesi guru. PGRI telah membuat Kode Etik Guru yang disebut dengan Kode Etik Guru Indonesia (KEGI). KEGI ini merupakan hasil Konferensi Pusat PGRI Nomor V/Konpus II/XIX/2006 tanggal 25 Maret 2006 di Jakarta yang disahkan pada Kongres XX PGRI No. 07/Kongres/XX/PGRI/2008 tanggal 3 Juli 2008 di Palembang. KEGI ini dapat menjadi Kode Etik tunggal bagi setiap orang yang menyandang profesi

tentang betapa agung dan beratnya jabatan guru itu dan betapa besar pula dan berat tanggung jawabnya.

${ }^{14}$ R.A. Soepardi Hadiatmadja, dkk., Pedidikan Sejarah Perjuangan PGRI (PSP PGRI), Jilid II, III, IV, V ( Semarang : IKIP PGRI, 1998), 6-7. 
guru di Indonesia atau menjadi referensi bagi organisasi atau asosiasi profesi guru selain PGRI untuk merumuskan Kode Etik bagi anggotanya. ${ }^{15}$

Prinsip-prinsip yang ada dalam Kode Etik Guru Indonesia ini selaras dengan prinsip-prinsip azasi "A code ethics for the teaching profession" yang dirumuskan oleh The National Educatioan Association. Di dalam Kongres PGRI mengenai kode etik antara lain disebutkan bahwa pendidikan suatu bidang pengabdian terhadap Tuhan Yang Maha Esa, bangsa dan tanah air serta kemanusiaan pada umumnya.16 Bahwa guru Indonesia berjiwa Pancasila dan UUD 1945 merasa bertanggung jawab atas terwujudnya cita-cita proklamasi kemerdekaan RI.

\section{Profesionalisme Guru dalam Pembelajaran}

Menurut Undang-undang Republik Indonesia No. 20 Tahun 2003 tentang Sistem Pendidikan Nasional (Sisdiknas) bab I pasal 1 ayat 20 dikatakan bahwa pembelajaran adalah proses interaksi peserta didik dengan pendidik dan sumber belajar pada suatu lingkungan belajar.17 Oemar Hamalik, mengatakan bahwa pembelajaran adalah suatu kombinasi yang tersusun meliputi unsur-unsur manusiawi, material, fasilitas, perlengkapan, dan prosedur yang saling mempengaruhi mencapai tujuan pembelajaran. ${ }^{18}$ Manusia terlibat dalam sistem pengajaran terdiri dari siswa, guru, tenaga lainnya, misalnya tenaga laboratorium. Material, meliputi buku-buku, papan tulis, kapur, dan lain-lain. Fasilitas dan perlengkapan, terdiri dari ruangan kelas, perlengkapan audio visual, komputer dan lain-lain. Prosedur, meliputi jadwal dan metode penyampaian informasi, praktik, belajar, ujian dan sebagainya.

Jika dikaitkan dengan pembelajaran, maka dapat diperoleh sebuah pengertian bahwa pembelajaran adalah upaya membelajarkan siswa untuk dapat memahami, menghayati dan mengamalkan melalui kegiatan bimbingan, pelajaran atau latihan.

1. Hambatan-hambatan Profesionalitas Guru dalam Pembelajaran

Kemerosotan pendidikan sudah dirasakan selama bertahun-tahun, untuk kesekian kalinya kurikulum dituding sebagai penyebabnya. Hal ini tercermin dengan adanya upaya mengubah kurikulum mulai kurikulum 1975 diganti dengan kurikulum 1984, kemudian diganti lagi dengan kurikulum 1994, kemudian diganti dengan Kurikulum Berbasis Kompetensi.

\footnotetext{
15 Thomas Gardon dan Mudjito, Guru yang Efektif(Jakarta: Rajawali, 1990), 105.

16 Hendiyat Soetopo dan Wasty Soemanto, Kepemimpinan dan Supervisi Pendidikan (Jakarta: Bina Aksara, tt). 289-290.

17 Soetopo, Kepemimpinan dan Supervisi Pendidikan, 5.

18 Oemar Hamalik, Kurikulum dan Pembelajaran (Jakarta: Bumi Aksara, 2003), 57.
} 
Akadum, menyatakan bahwa rendahnya keprofesionalan guru disebabkan oleh antara lain: (1) masih banyak guru yang yang tidak menekuni profesinya secara utuh. Hal ini disebabkan oleh banyak guru yang bekerja di luar jam kerjanya untuk memenuhi kebutuhan hidup sehari-hari sehingga waktu untuk membaca dan menulis untuk meningkatkan diri tidak ada, (2) kemungkinan disebabkan oleh adanya perguruan tinggi swasta sebagai pencetak guru yang lulusannya asal jadi tanpa memperhitungkan outputnya kelak di lapangan sehingga menyebabkan banyak guru yang tidak patuh terhadap etika profesi keguruan, (3) kurangnya motivasi guru dalam meningkatkan kualitas guru tidak ditintut untuk meneliti sebagaimana yang diberlakukan pada dosen di perguruan tinggi.19 Dunia pendidikan masih terbelenggu dengan dua masalah yang pemecahannya memerlukan kearifan dan kebijaksanaan beberapa pihak terutama pengambil kebijakan: 1) profesi keguruan kurang menjamin kesejahteraan karena rendahnya gaji, 2) keprofesionalan guru masih rendah. ${ }^{20}$

Mulyasa mengungkapkan beberapa kesalahan yang sering dilakukan oleh guru dalam pembelajaran yaitu: Pertama, Mengambil jalan pintas dalam pembelajaran. Tugas guru dalam pembelajaran tidak terbatas pada penyampaian informasi kepada peserta didik. Sesuai kemajuan dan tuntutan zaman, guru harus memiliki kemampuan untuk memahami peserta didik dengan berbagai keunikannya agar mampu membantu mereka dalam menghadapi kesulitan. Dalam pada itu, guru dituntut memahami berbagai model pembelajaran yang efektif agar dapat membimbing peserta didik secara optimal.

Dalam kaitannya dengan perencanaan, guru dituntut untuk membuat persiapan mengajar yang efektif dan efisien. Namun dalam kenyataannya, dengan berbagai alasan banyak guru yang mengambil jalan pintas dengan tidak membuat persiapan ketika mau melakukan pembelajaran, sehingga guru mengajar tanpa persiapan. Mengajar tanpa pesiapan di samping merugikan guru sebagai tenaga profesional juga akan sangat mengganggu perkembangan peserta didik.Ada kalanya guru membuat persiapan mengajar tertulis hanya untuk memenuhi tuntutan administrative atau disuruh oleh kepala sekolah karena akan ada pengawasan ke sekolahnya. ${ }^{21}$

Kedua, Menunggu peserta didik berperilaku negative. Dalam pembelajaran di kelas, kebanyakan guru terperangkap dengan pemahaman yang keliru tentang mengajar. Mereka menganggap mengajar adalah

\footnotetext{
19 http: // www. Suara Pembaruan. Diakses pada 01 Desember 2016.

20 http: // www. Suara Pembaruan.

${ }^{21}$ Lihat E. Mulyasa, Menjadi Guru Profesional (Bandung: Remaja Rosdakarya, 2005.
} 
menyampaikan materi kepada peserta didik, mereka juga menganggap mengajar adalah memberikan sejumlah pengetahuan kepada peserta didik. Tidak sedikit guru yang sering mengabaikan perkembangan kepribadian peserta didik, serta lupa memberikan pujian kepada mereka yang berbuat baik, dan tidak membuat masalah. Biasanya guru baru bisa memberikan perhatian kepada peserta didik ketika ribut, tidak memperhatikan atau mengantuk di kelas, sehingga menunggu peserta didik berperilaku buruk. Kondisi tersebut seringkali mendapat tanggapan yang salah dari peserta didik. Mereka beranggapan bahwa jika ingin mendapat perhatian atau diperhatikan guru, maka harus berbuat salah, beruat gaduh, mengganggu, dan melakukan tindakan indisiplin lainnya.

Ketiga, mengabaikan perbedaan peserta didik. Kesalahan yang sering dilakukan oleh guru dalam pembelajaran adalah mengabaikan perbedaan individu peserta didik. Setiap peserta didik memiliki perbedaan individual sangat mendasar yang perlu diperhatikan dalam pembelajaran. Peserta didik memiliki emosi yang sangat bervariasi dan sering memprlihatkan sejumlah perilaku yang tampak aneh. Pada umumnya, perilaku-perilaku tersebut relatif normal dan cukup bisa ditangani dengan menciptakan iklim pembelajaran yang kondusif. Akan tetapi, karena guru di sekolah dihadapkan pada sejumlah peserta didik, guru seringkali kesulitan untuk mengetahui mana perilaku yang normal dan wajar, serta mana perilaku yang indisiplin dan perlu mendapat penanganan khusus.

Keempat, merasa paling pandai. Kesalahan lain yang sering dilakukan oleh guru dalam pembelajaran adalah merasa paling pandai. Kesalahan ini berangkat dari kondisi bahwa pada umumnya para peserta didik di sekolah usianya relatif lebih muda dari gurunya, sehingga guru merasa bahwa peserta didik tersebut lebih bodoh dibandingkan dengan dirinya, peserta didik dipandang sebagai gelas yang perlu diisi air ke dalamnya.

Kelima, Tidak adil. Keadilan dalam pembelajaran merupakan kewajiban guru dalam pembelajaran dan hak peserta didik untuk memperolehnya. Dalam prakteknya banyak guru yang tidak adil, sehingga merugikan perkembangan peserta didik dan ini merupakan kesalahan yang sering dilakukan oleh guru, terutama dalam penilaian. ${ }^{22}$ Berdasarkan permasalahan tersebut, maka seorang guru harus mampu memahami kondisi-kondisi yang memungkinkan dirinya berbuat salah, dan yang paling penting adalah mengendalikan diri serta menghindari dari kesalahan-kesalahan.

22 E. Mulyasa, Menjadi Guru Profesional (Bandung: Remaja Rosdakarya, 2005), 28. 
2. Upaya-upaya profesionalitas Guru dalam Pembelajaran

Pemerintah talah berupaya untuk meningkatkan keprofesionalan guru diantaranya adalah persyaratan jenjang pendidikan yang lebih tinggi bagi tenaga pengajar. Upaya lain yang dilakukan pemerintah adalah program sertifikasi yang dilakukan oleh Direktorat Pembinaan Perguruan Tinggi Agama Islam melalui Proyek Peningkatan Mutu Pendidikan Dasar. ${ }^{23}$

Pantiwati mengatakan bahwa selain sertifikasi upaya lain yang telah dilakukan di Indonesia untuk meningkatkan keprofesionalan guru adalah PKG (Pusat Kegiatan Guru), dan KKG (Kelompok Kerja Guru) yang memungkinkan para guru untuk berbagi pengalaman dalam memecahkan masalah-masalah yang mereka hadapi dalam kegiatan mengajarnya. ${ }^{24}$

Usaha lain yang dapat dilakukan oleh guru untuk meningkatkan keprofesionalan guru dalam pembelajaran yaitu: Pertama, Penguasaan bahan, yang meliputi: menguasai dan mengkaji kurikulum pendidikan dasar serta menguasai bahan pengajaran, mengkaji kurikulum dan menelaah buku teks pendidikan, menelaan dan berlatih melaksanakan kegiatan-kegiatan yang dinyatakan dalam buku teks pedoman studi, mengkaji bahan penunjang yang relevan dengan bahan studi dan yang relevan dengan profesi guru. ${ }^{25}$

Kedua, mengelola program belajar-mengajar. Dalam mengelola program belajar-mengajar ini guru dapat berusaha dengan cara: menyusun program pengajaran dengan cara mengkaji ciri-ciri tujuan pengajaran dan berlatih merumuskan serta menetapkan tujuan, berlatih memilih dan mengembangkan tujuan yang akan dicapai dengan mengembangkan bahan sesuai dengan tujuan, memilih dan berlatih mengkaji, mengembangkan strategi belajar-mengajar dengan penggunaan metode, media dan memanfaatkan sumber belajar. ${ }^{26}$

Ketiga, mengelola kelas. Usaha yang dapat dilakukan oleh guru dalam mengelola kelas antara lain: mengatur ruangan belajar dengan berlatih dan mengkaji data ruang belajar-mengajar, penggunaan serta berusaha menata ruangan yang rapi agar siswa senang dan kerasan menggunakannya, menciptakan iklim belajar yang tepat dengan cara mengkaji prinsip-prinsip pengelolaan kelas, faktor-faktor yang mempengaruhi, menciptakan suasana belajar serta berlatih menangani masalah pengajaran dan pengelolaan. ${ }^{27}$ Keempat, Menggunakan media/sumber belajar, yang meliputi: mengkaji

\footnotetext{
${ }^{23}$ Mulyasa, Menjadi Guru Profesional, 1-2.

24 Pantiwati, Upaya Peningkatan Keprofeionalan Guru Melalui Program Sertifikasi Guru Bidang Studi (Malang: PSSJ PPS Universitas Malang), 30.

25 Cece Wijaya, Kemampuan Dasar Guru dalam Proses Belajar-Mengajar (Bandung: Remaja Rosdakarya, 1991), 25.

26 Wijaya, Kemampuan Dasar Guru dalam Proses Belajar-Mengajar, 26.

27 Wijaya, Kemampuan Dasar Guru dalam Proses Belajar-Mengajar, 27.
} 
berbagai media pengajaran yang sesuai dengan bahan yang disajikan, berlatih memilih membuat dan menggunakan media pengajaran. ${ }^{28}$

Kelima, menguasai landasan pendidikan, yang melipputi: mengenal dan mengkaji tujuan pendidikan dasar untuk mencapai tujuan pendidikan nasional, mengkaji kegiatan-kegiatan pengajaran yang menunjang pencapaian tujuan pendidikan nasional. ${ }^{29}$ Keenam, terampil dalam melakukan interaksi para siswa dengan mempertimbangkan tujuan dan bahan pelajaran, kondisi siswa, suasana belajar, jumlah siswa, dan waktu yang tersedia. ${ }^{30}$ Ketujuh, penilaian prestasi belajar. Penilaian dalam proses belajar-mengajar berfungsi sebagai alat untuk mengukur tercapai-tidaknya tujuan pembelajaran. Melalui penilaian dapat ditetapkan apakah proses tersebut berhasil atau tidak. ${ }^{31}$

Sedangkan usaha yang dapat dilakukan dari pihak sekolah antara lain: Pertama, penyediaan sarana dan prasarana yang memadai. Mengingat tugas guru demi tercapainya tujuan yang optimal, maka penyediaan sarana ini hendaknya jangan dijadikan alasan untuk tidak menyediakan sarana karena masih banyak usaha lain yang dapat ditempuh untuk mengatasinya. Dan perlu diperhatikan, penyediaan sarana ini dimaksud tidak terbatas pada buku paket saja, tetapi perlu dilengkapi dengan alat-alat praktikum, laboratorium, buku perpustakaan, mpbiler, dan perbaikan gedung sekolah. ${ }^{32}$ Dengan adanya sarana yang memadai maka guru dapat melaksanakan tugasnya secara efektif dan efisien sehingga dapat membantu menunang keberhasilan yang dimaksud.

Kedua, Perhatian terhadap sosial ekonomi guru. Suatu kenyataan yang tidak dapat dipungkiri bahwa penghasilan guru itu sekarang, standar kehidupan bagi guru tidak seimbang dengan biaya kehidupan. Oleh karena itu, perbaiakan insentive kepada guru sedemikian rupa sehingga menimbulkan gairah yang besar, dalam mengajar memerlukan ketenangan batin dan hal itu akan tercapai kalau kebutuhan materialnya tercukupi. Maka, untuk menciptakan guru yang benar-benar memahami tugasnya dengan kesadaran penuh untuk diusahakan keseimbangan antara tugas dan kebutuhan tugas dan kesejahteraan guru. ${ }^{33}$

\footnotetext{
${ }^{28}$ Moh. Uzer Oesma, Menjadi Guru Profesional (Bandung: Remaja Rosdakarya, 1992),118.

${ }^{29}$ Wijaya, Kemampuan Dasar Guru dalam Proses Belajar-Mengajar, 28.

30 Nana Sudjana, Cara Belajar Siswa Aktif dalam Proses Belajar Mengajar (Bandung: Sinar Dunia, 1989), 37.

${ }^{31}$ Sudjana, Cara Belajar Siswa Aktif dalam Proses Belajar Mengajar, 65.

32 ST. Vembriato, Kapita Selekta Pendidikan (Yogyakarta: Yayasan Pendidikan Paramita, 1984), 35.

33 Dirawat, Busro Lembari dan Soekarno Indra Fachrudi, Pengantar Kepemimpinan Pendidikan (Surabaya: Usaha Nasional, 1981), 108-109.
} 
Ketiga, tanggung jawab dan pengawasan. Kepala sekolah mempunyai peranan pimpinan yang sangat berpengaruh dari lingkungan sekolah yang menjadi tanggung jawabnya. Tugas kepala sekolah selaku pemimpin ialah membantu para guru untuk mengembangkan kesanggupan-kesanggupan mereka secara maksimal dan menciptakan suasana hidup sekolah yang mendorong guru-guru, pegawai-pegawai tata usaha, siswa dan orang tua siswa untuk mempersatukan kehendak pikiran dan tindakan dalam kegiatan-kegiatan kerja sama yang efektif bagi tercapainya tujuan-tujuan sekolah. ${ }^{34}$ Sedangkan pengawasan merupakan upaya untuk meningkatkan kinerja guru dan mempunyai tindakan preventif untuk mencegah agar para guru tidak melakuakan penyimpangan dan lebih berhati-hati dala melaksanakan pekerjaannya. ${ }^{35}$

Keempat, rapat guru. Rapat guru yang diadakan di sekolah merupakan salah satu upaya peningkatan keprofesionalan guru. Dalam rapat, seluruh tenaga kependidikan memiliki kesempatan untuk menyampaikan berbagai ide, gagasan, saran, pandangan, dan pendapat secara langsung terhadap suatu masalah yang berhubungan dengan pembelajaran khususnya, dan masalahmasalah yang berhubungan dengan kemajuan sekolah pada umumnya. ${ }^{36}$ Dengan demikian, rapat di sekolah menjadi bagian penting dalam memecahkan masalah, baik yang berkaitan dengan peserta didik, tenaga kependidikan maupun pengembangan sekolah ke arah yang lebih baik.

Kelima, penataran. Penataran merupakan salah satu teknik upaya peningkatan keprofesionalan guru baik itu guru agama maupun guru umum. Hal ini sesuai dengan pengertian penataran, yaitu suatu usaha yang bertujuan untuk meninggikan taraf ilmu pengetahuan dan kecakapan para pegawai, guruguru atau petugas lainnya sehingga keahliannya bertambah luas dan mendalam. ${ }^{37}$ Berdasarkan pengertian tersebut, dapat diketahui bahwa melalui penataran ini diharapkan pengetahuan dan kemampuan guru berkembang dan selanjutnya ia dapat melaksanakan tugasnya dengan efektif dan efisien.

${ }^{34}$ M. Ngalim Purwanto, Administrasi dan Supervisi Pendidikan (Bandung: Remaja Rosdakarya, 1993), 73-74.

35 E. Mulyasa, Menjadi Kepala Sekolah Profesional dalam Konteks Menyukseskan MBS dan KBK (Bandung: Remaja Rosdakarya, 2004), 111.

${ }^{36}$ Mulyasa, Menjadi Kepala Sekolah Profesional dalam Konteks Menyukseskan MBS dan KBK, 112.

37 M. Ngalim Purwanto, Administrasi Pendidikan (Yogyakarta: Mutiara, 1984), 68. 


\section{Kode Etik Guru dalam Meningkatkan Profesionalitas Guru Terhadap Pembelajaran Di MA Darul Amin Pamekasan}

Kode Etik Guru merupakan usaha pendidikan untuk mencapai cita-cita luhur bangsa dan negara Indonesia sebagaimana termaktub dalam pembukaan UUD 1945 yang mutlak diperlukan sebagai sarana yang teratur dan tertib sebagai pedoman yang merupakan tanggung jawab bersama. Oleh karena itu, guru di MA Darul Amin dituntut memiliki persyaratan tertentu dalam menjalankan tugas dan tanggung jawabnya dengan baik. MA Darul Amin Pamekasan merumuskan kode etik guru, di antaranya: 38

- Semua guru harus Taat kepada kepada semua peraturan sekolah

- Semua guru harus ada di ruang guru selambat-lambatnya 15 menit sebelum proses pelajaran dimulai

- Guru harus siap mengajar dan mengabdikan diri pada pendidikan selama 24 jam di MA Darul Amin pamekasan.

- Kasih sayang pada peserta didik dan meperlakukan mereka laksana anak sendiri.

- Guru tidak boleh mengajar di lembaga lain.

- Guru diwajibkan membuat perangkat pembelajaran dalam mengajar.

- Guru senantiasa menampakan prilaku muslim yang taat dan disiplin, minimal di tempat yang langsung bersinggungan dengan peserta didik, karena guru menjadi cerminan kepribadian peserta didik.

- Guru wajib dengan sigap menegur murid yang perilakunya kurang terpuji secara langsung atau tidak.

- Guru hendak mengamalkan ilmunya dan jangan sampai perbuatan bertentangan dengan ucapannya.

- Guru yang datang terlambat sampai 3x dalam sebulan, diberi peringatan dan teguran oleh pihak yayasan.

- Urusan keluarga harus dikerjakan di luar sekolah atau waktu libur sehingga tidak menggunakan hari sekolah.

- Ikut bertanggung jawab atas keberhasilan, keamanan, ketertiban kelas dan sekolah pada umumnya

- Ikut bertanggung jawab atas pemeliharaan gedung, halaman, perabot dan peralatan sekolah

- Membantu kelancaran pelajaran baik di kelasnya maupun di sekolah pada umumnya

- Ikut menjaga nama baik sekolah umumnya baik di dalam maupun di luar sekolah.

- Ikut membantu agar tata tertib sekolah dapat berjalan dan ditaati

${ }^{38}$ Hasil dokumentasi penulis di MA Darul Amin Pamekasan.

Jurnal Pendidikan Agama Islam

Volume 4 Nomor 2 Nopember 2016

ISSN(p) 2089-1946\& ISSN(e) 2527-4511

Hal. 284 - 292 
- Meninggalkan sekolah selama pelajaran berlangsung penyimpangan dalam hal ini hanya dengan ijin kepala sekolah

- Tidak boleh merokok di dalam dan di luar sekolah

- Tidak boleh Mengganggu jalannya pelajaran baik terhadap kelasnya maupun terhadap kelas lain

- Tidak boleh memari peserta didik dengan cara kekerasan.

Dengan kode etik di atas, para guru wajib melaksanakan dengan penuh tanggung jawab, demi terlaksananya pendidikan yang baik di MA Darul Amin ini. Lebih lanjut Bapak M. Subaidi, BA, menjelaskan:

“...Kode Etik Guru merupakan usaha pendidikan untuk mencapai cita-cita luhur bangsa dan negara Indonesia sebagaimana termaktub dalam pembukaan UUD 1945 yang mutlak diperlukan sebagai sarana yang teratur dan tertib sebagai pedoman yang merupakan tanggung jawab bersama. Oleh karena itu, guru di sekolah ini dituntut memiliki persyaratan tertentu dalam menjalankan tugas dan tanggung jawabnya dengan baik..."39

Pernyataan Bapak Ahmad Rofi'i, M.Ag, di atas merupakan kewajiban bagi guru untuk memenuhi persyaratan tertentu dalam mengajar. Dan dari data yang penulis dapat dari MA Darul Amin, diketahui tentang pendidikan terakhir guruguru di sekolah ini yaitu S I. Mereka telah memiliki ijazah keguruan yang menjadi syarat dari profesi seorang guru. Hal ini menunjukkan bahwa guru telah memiliki kualifikasi yang tinggi sebagai guru di MA Darul Amin Pamekasan.

Di sisi lain, dalam proses pembelajaran pengalaman guru dalam mengajar menentukan keberhasilan proses pembelajaran. Guru yang masa kerjanya cukup lama memiliki pengalaman yang relatif banyak dibandingkan dengan guru yang baru mengajar. Selama menjadi guru, ia dapat menilai kemampuan sekaligus memperbaiki sehingga kemampuan yang dimikili juga semakin mantap. Hal tersebut tentu saja berkaitan untuk selalu meningkatkan kemampuannya.

Berdasarkan hasil wawancara dengan Bapak Mahfud, S.Pd, selaku Waka Kurikulum pada tanggal 06 Desember 2016 pada jam 08.30 dan observasi serta diperkuat dengan dokumentasi, menunjukkan bahwa pengalaman mengajar yang dijalani oleh guru di MA Daru Amin adalah salah satu faktor penting yang menentukan keberhasilan pembelajaran. Dan itu merupakan tanggung jawab guru atas proses pembelajaran yang termaktub dalam kode etik MA Darul Amin Pamekasan. ${ }^{40}$

Lebih lanjut Bapak Mahfud, S.Pd menegaskan:

"..Guru memiliki kesempatan untuk mengembangkan atau meningkatkan kualitasnya sehingga dapat menunjukkan tugas-tugas mengajar dengan lebih mantap dan memudahkan untuk meningkatkan kualitas yang telah dimilikinya. Frekuensi

${ }^{39}$ Hasil wawancara dengan Bapak M. Subaidi, BA, selaku Kepala MA Darul Amin Pamekasan, pada 02 Desember 2016.

40 Hasil wawancara dengan Bapak Mahfud S.Pd selaku Waka Kurikulum di MA Darul Amin Pamekasan, pada 06 Desember 2016. 
pengalaman guru mengajar tersebut, diimplementasikan terhadap kegiatan guru dalam mengajar dan mendidik siswa.." 41

Seorang guru dalam melaksanakan tugasnya harus membuat perencanaan atau persiapan mengajar agar pengajaran dapat terarah pada pencapaian tujuan. Mengenai rencana pembelajaran, guru di MA Darul Amin selalu membuat persiapan mengajar. Dalam hal ini Ibu Siti Rahmah, S.Pd.I pada hari Senin, mengatakan bahwa ia selalu membuat rencana pembelajaran dan silabus.

"Ketika mau mengajar, saya selalu mempersiapkan RPP. Tapi, dalam pembelajaran tidak selalu sesuai dengan rencana pembelajaran yang saya buat, karena kenyataan yang ada di dalam kelas tidak selalu sesuai dengan yang direncanakan." 42

Hal ini menunjukkan bahwa semua guru di MA Darul Amin Pamekasan, sudah menyadari arti pentingnya persiapan mengajar bagi persiapan tujuan pengajaran karena dari pembuatan persiapan mengajar dapat diketahui penguasaan guru terhadap materi yang akan disampaikan, mengingat mata pelajaran dapat berkembang. Oleh karena itu, persiapan megajar dapat dijadikan pedoman pengajaran agar terarah dan tidak simpang siur dalam pencapaian tujuan.

Dari data yang penulis dapat dari MA Darul Amin, diketahui tentang pendidikan terakhir rata-rata para guru di sekolah ini yaitu SI dan ada sebagian yang sudah menempuh jenjang S II. Mereka telah memiliki ijazah keguruan yang menjadi syarat dari profesi seorang guru. Hal ini menunjukkan bahwa guru telah memiliki kualifikasi yang tinggi sebagai guru di MA Darul Amin Desa Waru Barat Kecamatan Waru Pamekasan.

Di sisi lain, dalam proses pembelajaran pengalaman guru dalam mengajar menentukan keberhasilan proses pembelajaran. Guru yang masa kerjanya cukup lama memiliki pengalaman yang relatif banyak dibandingkan dengan guru yang baru mengajar. Selama menjadi guru, ia dapat menilai kemampuan sekaligus memperbaiki sehingga kemampuan yang dimikili juga semakin mantap. Hal tersebut tentu saja berkaitan untuk selalu meningkatkan kemampuannya.

"Pengalaman mengajar yang dijalani oleh guru di MA Daru Amin adalah salah satu faktor penting yang menentukan keberhasilan pembelajaran. Dan itu merupakan tanggung jawab guru atas proses pembelajaran yang termaktub dalam kode etik MA Darul Amin Pamekasan.."43

Para guru di MA Darul Amin dalam melaksanakan tugasnya harus membuat perencanaan atau persiapan mengajar agar pengajaran dapat terarah pada pencapaian tujuan. Hal ini menunjukkan bahwa semua guru di MA Darul Amin Pamekasan, sudah menyadari arti pentingnya persiapan mengajar bagi

${ }^{41}$ Hasil wawancara dengan Bapak Mahfud S.Pd selaku Waka Kurikulum di MA Darul Amin Pamekasan, pada 06 Desember 2016.

42 Hasil wawancara dengan Ibu Siti Rahmah, S.Pd.I, selaku guru PAI di MA Darul Amin Pamekasan, pada 10 Desember 2016.

43 Hasil wawancara dengan Bapak Mahfud S.Pd selaku Waka Kurikulum di MA Darul Amin Pamekasan, pada 17 Desember 2016.

Jurnal Pendidikan Agama Islam

Volume 4 Nomor 2 Nopember 2016

ISSN(p) 2089-1946\& ISSN(e) 2527-4511

Hal. 286 - 292 
persiapan tujuan pengajaran karena dari pembuatan persiapan mengajar dapat diketahui penguasaan guru terhadap materi yang akan disampaikan, mengingat mata pelajaran dapat berkembang. Oleh karena itu, persiapan megajar dapat dijadikan pedoman pengajaran agar terarah dan tidak simpang siur dalam pencapaian tujuan.

Pelaksanaan tugas mengajar, guru di MA Darul Amin harus dapat mengetahui berbagai metode mengajar dan dapat menggunakann semua metode dengan pokok bahasan yang diberikan dan situasi belajar yang ada. Para guru di MA Darul Amin menggunakan metode yang bervariasi, di antaranya adalah metode ceramah, metode drill, metode diskusi, metode demonstrasi dan lainlain. Karena metode tersebut adalah metode yang baik dan cocok untuk manyampaikan materi pelajaran. Selain metode tersebut, guru juga menggunakan metode kerja kelompok, hal ini digunakan untuk mengukur atau mengetahui keaktifan dan kedisiplinan siswa dalam belajar. Oleh karena itu, setiap guru harus dapat menggunakan dan menguasai metode-metode tersebut, karena penggunaan metode yang tepat dan sesuai dengan situasi dan kondisi dapat menumbuhkan minat belajar siswa terhadap mata pelajaran yang diberikan oleh guru.

Selain itu, guru menggunakan media dalam mengajar, misalnya: TV, tape recorder, DVD, dan lain sebagainya. Sedangkan untuk menumbuhkan situasi interaksi yang baik antara guru dan siswa, seorang guru perlu menciptakan suasana belajar yang harmonis yang penuh dengan keakraban dan kekeluargaan. Dengan demikian, siswa akan belajar dengan sungguh-sungguh dan akan mengamalkan materi yang sudah dipelajarinya dalam kehidupan sehari-hari.

Faktor lain yang tidak kalah pentingnya dalam pencapaian tujuan pembelajararan adalah evaluasi. Evaluasi berfungsi untuk mengukur tinggi rendahnya tingkat keberhasilan siswa terhadap proses pengajaran yang telah dilaksanakan oleh guru. Evaluasi tersebut tidak hanya terbatas pada test semester, tetapi dapat dilakukan pada setiap pelaksanaan pengajaran dalam pembelajaran untuk mengetahui hasil belajar siswa.

“...Para guru di MA Darul Amin biasanya mengadakan evaluasi pada setiap selesai satu pokok bahasan dan guru mengadakan tanya jawab kepada siswa jika akan memulai pembelajaran. Hal tersebut dimaksudkan agar siswa selalu siap pada saat pembelajaran dimulai.." 44

Sedangkan tanggung jawab dan komitmen guru di MA Darul Amin terhadap tugasnya ditandai dengan sikap mereka apabila mereka berhalangan hadir untuk mengajar mereka selalu memberi tahu kepada Kepala Sekolah atau guru piket dan untuk tanggung jawabnya terhadap siswa mereka memberi tugas seperti mengerjakan Lembar Kerja Siswa kemudian dibahas bersama-sama dan diberi nilai agar siswa tetap semangat dalam belajar.

${ }^{44}$ Hasil wawancara dengan Bapak M. Subaidi, BA, selaku Kepala MA Darul Amin Pamekasan, pada 19 Desember 2016. 
Jika ada guru yang merasa berkepentingan meningkatkan kualitasnya, maka ia akan tergerak untuk melakukan usaha-usaha yang dapat menunjang peningkatan wawasan pengetahuan, sikap dan keterampilan, baik melalui kegiatan-kegiatan yang diselenggarakan oleh sekolah seperti rapat, seminar, penataran, dan sebagainya. Hal itu merupakan aturan sekolah yang harus dipatuhi oleh semua guru di MA Darul Amin Pamekasan.

\section{E. Pengembangan Kode Etik Guru untuk Peningkatan Profesionalitas Guru dalam Pembelajaran di MA Darul Amin}

Beberapa faktor yang menunjang keberhasilan peningkatan profesionalitas guru di MA Darul Amin, di antaranya adalah faktor kepala madrasah, profesionalitas kepala madrasah sangat menentukan perjalanan suatu lembaga pendidikan. Sampai sejauh mana kepala madrasah mengambil kebijakan terhadap berbagai hal untuk mengembangkan lembaganya, termasuk kebijakankebijakannya terhadap tenaga pengajar dan staf aministrasi.

Pola kerja MA Darul Amin Pamekasan, tidak terfokus pada kepala madrasah, tetapi membentuk kerjasama tim (team work) yang solid dan dapat dikatagorikan sebagai kerja tim yang padu dalam menangani segala urusan pendidikan. Sehingga dalam kebijakan-kebijakan dan strategi sistem Madrasah Aliyah dapat membawa MA Darul Amin Pamekasan pada prestasi yang gemilang.

"Di MA Darul Amin, kiranya kewajiban guru dapat dikelompokkan menjadi dua komponen yaitu bahwa guru berbakti membimbing anak seutuhnya dan guru membimbing anak agar menjadi manusia pembangunan yang ber-pancasila. Yang dimaksud dengan manusia seutuhnya adalah manusia dewasa jasmani dan rohani, selain itu juga mempunyai intelektual, sosial maupun segi-segi lainnya pada pribadi anak didik yang sesuai dengan hakikat pendidikan.." 45

Guru harus memiliki kejujuran profesional dalam menerapkan kurikulum sesuai dengan kebutuhan anak didik masing-masing. Guru menghargai dan memperhatikan perbedaan daya pikir dan kebutuhan anak didiknya masingmasing. Di sisi lain, guru hendaknya luwes dalam menerapkan kurikulum sesuai dengan kebutuhan anak didik masing-masing.

Guru harus memperhatikan karakter, pola pikir dan kondisi anak didik. Selain itu, anak didik harus dikondisikan agar lebih aktif di kelas. Dalam hal ini, guru berperan sebagai fasilitator. Sehingga proses pembelajaran berlangsung dinamis. Dengan begitu, siswa akan merasa senang dengan proses pembelajaran tersebut.

Di sekolah ini, guru harus mengusahakan terciptanya kerjasama yang sebaik-baiknya antara sekolah, orang tua murid, dan masyarakat bagi kesempurnaan usaha pendidikan atas dasar kesadaran bahwa pendidikan merupakan tanggung jawab bersama antara pemerintah, orang tua murid dan

\footnotetext{
45 Hasil wawancara dengan Bapak M. Subaidi, BA, selaku Kepala MA Darul Amin Pamekasan, pada 22 Desember 2016.
}

Jurnal Pendidikan Agama Islam

Volume 4 Nomor 2 Nopember 2016

ISSN(p) 2089-1946\& ISSN(e) 2527-4511

Hal. 288 - 292 
masyarakat. Dengan begitu, sinergitas antara guru, pihak sekolah, siswa, walisiswa dan masyarakat terjalin dengan baik. Sehingga pelaksanaan pendidikan di MA Darul Amin Pamekasan berjalan sesuai dengan harapan.

Guru secara bersama-sama memelihara, membina dan meningkatkan organisasi guru profesional sebagai sarana pengabdian. Dalam hal ini, guru harus menjadi anggota dan membantu organisasi guru yang bermaksud membina profesi dan pendidikan pada umumnya. Guru senantiasa berusaha terciptanya persatuan di antara sesama pengabdi pendidikan. Selanjutnya, guru senantiasa berusaha agar menghindarkan diri dari sikap-sikap, ucapan-ucapan, dan tindakan-tindakan yang tercela serta merugikan organisasi.

“Bapak Kepala MA Darul Amin telah memberikan kesempatan dan dorongan kepada para guru untuk melanjutkan studinya ke jenjang yang lebih tinggi dan mengikuti kegiatan-kegiatan lain yang dapat meningkatkan pengalaman dan profesionalitasnya.." 46

Seseorang pendidik dituntut mampu memainkan peranan dan fungsinya dalam menjalankan tugas keguruannya. Hal ini menghindarkan adanya benturan fungsi dan peranannya, sehingga pendidik dapat menempatkan kepentingan sebagai individu, anggota masyarakat, warga negara, dan pendidik sendiri. Antara tugas keguruan dan tugas lainnya harus ditempatkan menurut proporsinya.

Kadang kala seseorang terjebak dalam sebutan pendidik, misalnya ada sebagian orang yang mampu memberikan dan memindahkan ilmu pengetahuan (transfer of learning) kepada seseorang. Sesungguhnya seseorang pendidik bukan hanya bertugas itu saja, tetapi pendidik bertanggung jawab atas pengolaan (manager of learning), pengarah pendidikan (director of learning) fasilitator, dan perencana (the planner of future society).

Upaya-upaya peningkatan profesionalitas guru di MA Darul Amin Pamekasan, telah dibuktikan dengan perombakan-perombakan atau perekrutanperekrutan guru yang layak dan profesional. Dalam hal kebijakan, berdasarkan temuan data yang didapatkan di lapangan melalui wawancara dengan kepala MA Darul Amin Pamekasan, dapat dideskripsikan bentuk-bentuk kebijakan, atau lebih tepatnya inovasi-inovasi kreatif yang telah dibangun bersama team worknya.

Sistem madrasah dan guru merupakan faktor yang paling menentukan akan keberhasikan anak didiknya. Hal inilah yang mendorong MA Darul Amin Pamekasan untuk meningkatkannya. Oleh sebab itu, langkah-langkah dan strategi yang harus diperhatikan adalah; rekruitmentasi guru, dan upaya peningkatan mutu serta profesionalitas melalui kode etik guru ataupun berbagai macam kegiatan baik secara formal maupun non formal.

46 Hasil wawancara dengan Bapak Mahfud S.Pd selaku Waka Kurikulum di MA Darul Amin Pamekasan, pada 27 Desember 2016. 
Dalam pengembangan kode etik selanjutnya, guna meningkatkan profesionalismenya, guru harus mengikuti seminar, penataran, dan workshop. Hasil wawancara ini merupakan kenyataan yang baik. Karena dengan adanya usaha dari pribadi guru untuk mengembangkan kemampuan dan kompetensinya sekaligus meningkatkan kualitas yang harus mereka miliki menunjukkan bahwa dedikasi dalam mengembangkan tanggung jawab mendidik masih tinggi.

Usaha-usaha selain yang dilakukan oleh guru tersebut juga ada usahausaha yang dilakukan oleh Kepala Sekolah yang harus diikuti dan dilaksanakan oleh guru untuk meningkatkan pengetahuan, sikap dan keterampilannya. Hal ini untuk menunjang pelaksanaan tugas guru di sekolah. Selain itu, beberapa upaya yang dilakukan oleh sekolah untuk meningkatkan profsionalismenya adalah, kedisiplinan dan pengawasan, rapat dan penataran yang diselenggarakan sekali dalam satu bulan.

“..Kedisiplinan sangat penting untuk membina pertumbuhan jabatan guru, dengan adanya kedisiplinan dan pengawasan yang baik dari Kepala Sekolah, maka guru akan lebih hati-hati dan bertanggung jawab terhadap tugas yang dibebankan kepadanya. Melalui pengawasan ini Kepala Sekolah harus memaksimalkan membantu memecahkan kesulitan yang dihadapi guru." 47

Kedisiplinan dan pengawasan ini diharapkan dapat menciptakan moral kerja yang baik di kalangan guru dan seluruh staf karyawan. Sedangkan rapat dilakukan untuk mengevaluasi pelaksanaan tugas guru serta membahas masalah-masalah yang ada kaitannya dengan pembelajaran di sekolah. Untuk memperluas pengetahuan hendaknya para guru lebih meningkatkan lagi usahausahanya dan sebagai Kepala Sekolah juga mengadakan jenis-jenis usaha dalam bentuk lain yang dapat menunjang peningkatan pengetahuan dan keterampilan yang baru agar para guru lebih berpengalaman.

Berdasarkan UU No. 14 Tahun 2005 tentang guru dan dosen (UUGD) pasal 10, maka dapat disimpulkan bahwa kode etik yang diterapka di MA Darul Amin Pamekasan lebih merujuk pada kompetensi pedagogik, kepribadian sosial. Para guru ditekankan memiliki kemampuan tersebut untuk meningkatkan kualitas proses pembelajan di kelas maupun proses pendidikan secara umum di MA Darul Amin Pamekasan.

Namun pada dasarnya, kode etik guru bertujuan agar para guru di MA Darul Amin harus menyadari bahwa proses pendidikan adalah bidang pengabdian kepada Tuhan Yang Maha Esa, Bangsa dan Negara serta kemanusiaan. Seorang guru harus berjiwa Pancasila dan setia pada UUD 1945, turut bertanggung jawab atas terwujudnya cita-cita proklamasi kemerdekaan Republik Indonesia 1945.

\footnotetext{
47 Hasil wawancara dengan Bapak M. Subaidi, BA, selaku Kepala MA Darul Amin Pamekasan, pada 25 Desember 2016.
} 


\section{F. Kesimpulan}

Kode etik guru di MA Darul Amin Pamekasan diterapkan agar usaha pendidikan untuk mencapai cita-cita luhur bangsa dan negara Indonesia sebagaimana termaktub dalam pembukaan UUD 1945 dapat terlaksana dengan baik. Karena pendidikan merupakan sarana yang teratur dan tertib yang merupakan tanggung jawab bersama. Oleh karena itu, guru di MA Darul Amin Pamekasan dituntut memiliki persyaratan tertentu dalam menjalankan tugas dan tanggung jawabnya dengan baik demi tercapainya tujuan pembelajaran. Dengan kode etik guru yang diterapkan di MA Darul Amin, maka setiap guru diwajibkan untuk mematuhi dan melaksanakannya. Dengan kode etik yang tertuang dalam beberapa item yang telah diapaparkan pada bab IV, telah terbukti dapat meningkatkan profesionalitas guru di MA Darul Amin Pamekasan.

Pengembangan kode etik di MA Darul Amin dilakukan agar kode etik yang telah ditetapkan semakin membuat guru memiliki dedikasi dan profesionalitas dalam proses pendidikan. Pengembangan ini berupaya agar kode etik yang ada lebih substansial dan aplikatif. Sehingga tujuan pendidikan secara umum di MA Darul Amin dapat tercapai. Di sisi lain, sistem pendidikan madrasah dan guru merupakan faktor yang paling menentukan akan keberhasikan anak didiknya. Hal inilah yang mendorong MA Darul Amin Pamekasan untuk meningkatkannya. Oleh sebab itu, langkah-langkah dan strategi yang harus diperhatikan adalah; rekruitmentasi guru, dan upaya peningkatan mutu serta profesionalitas melalui kode etik guru ataupun berbagai macam kegiatan baik secara formal maupun non formal.

\section{G. Referensi}

Bafadal, Ibrahim. Peningkatan Profesionalisme Guru Sekolah Dasar. Jakarta: Bumi Aksara, 2004.

Dirawat., Lembari, Busro., dan Fachrudi, Soekarno Indra. Pengantar Kepemimpinan Pendidikan. Surabaya: Usaha Nasional, 1981.

Djamarah, Syaiful Bahri. Guru dan Anak Didik Dalam Interaksi Edukatif. Jakarta : Rineka Cipta, 2000.

Gardon, Thomas dan Mudjito. Guru yang Efektif. Jakarta: Rajawali, 1990.

Hadiatmadja, R.A. Soepardi. Pedidikan Sejarah Perjuangan PGRI (PSP PGRI), Jilid II, III, IV, V. Semarang : IKIP PGRI, 1998.

Hadiyanto. Mencari Sosok Desentralisasi Manajemen Pendidikan Indonesia. Jakarta: Rineka Cipta, 2004.

Hamalik, Oemar. Kurikulum dan Pembelajaran. Jakarta: Bumi Aksara, 2003. 
Akhmad Zacky AR

Lillie, William. An Introduction to Ethics. New York : Barnes and Noble, 1996.

Mansor (al), Ansory. Jalan Kebahagiaan yang Diridhai. Jakarta : Raja Grafindo Persada, 1997.

Mulyasa, E. Menjadi Guru Profesional. Bandung: Remaja Rosdakarya, 2005. Menjadi Kepala Sekolah Profesional dalam Konteks Menyukseskan MBS dan KBK. Bandung: Remaja Rosdakarya, 2004.

Oesma, Moh. Uzer. Menjadi Guru Profesional. Bandung: Remaja Rosdakarya, 1992.

Pantiwati. Upaya Peningkatan Keprofeionalan Guru Melalui Program Sertifikasi Guru Bidang Studi. Malang: PSSJ PPS Universitas Malang, tt

Purwanto, M. Ngalim, Administrasi dan Suprvisi Pendidikan. Bandung: Remaja Rosdakarya, 1993. Administrasi Pendidikan. Yogyakarta: Mutiara, 1984.

Sardiman. Interaksi dan Motivasi Belajar Mengajar Pedoman Bagi Guru dan Calon Guru, Edisi I. Jakarta : Rajawali, 1992.

Soetjipto \& Kosasi, Raflis. Profesi Keguruan. Jakarta: Rineka Cipta, 1999.

Soetomo. Dasar-dasar Interaksi Belajar Mengajar. Surabaya : Usaha Nasional, 1993.

Soetopo, Hendiyat., \& Soemanto, Wasty. Kepemimpinan dan Supervisi Pendidikan. Jakarta: Bina Aksara, tt.

Subagyo. Pendidikan Kewarganegaraan. Semarang : IKIP Semarang Press, 2002.

Sudjana, Nana. Cara Belajar Siswa Aktif dalam Proses Belajar Mengajar. Bandung: Sinar Dunia, 1989.

Sutomo. Profesi Kependidikan. Semarang : IKIP Semarang Press, 1998.

Tim Pembina Mata Kuliah Didaktik Metodik/ Kurikulum IKIP Surabaya, Pengantar Didaktik Metodik Kurikulum PBM, Edisi I. Jakarta: Rajawali, 1989.

Vembriato, ST. Kapita Selekta Pendidikan. Yogyakarta: Yayasan Pendidikan Paramita, 1984.

Wijaya, Cece. Kemampuan Dasar Guru dalam Proses Belajar-Mengajar. Bandung: Remaja Rosdakarya, 1991.

http: // www. Suara Pembaruan. 